\title{
Fertilizer distribution mechanisms and side dress nitrogen fertilization in upland rice under no-tillage system
}

\author{
Carlos Alexandre Costa Crusciol ${ }^{1 *}$; André de Moraes Costa² ${ }^{2}$ Émerson Borghi ${ }^{3}$; Gustavo \\ Spadotti Amaral Castro ${ }^{4}$; Dirceu Maximino Fernandes ${ }^{5}$ \\ ${ }^{1}$ UNESP/FCA - Depto. de Produção Vegetal/Agricultura, C.P. 237 - 18603-970 - Botucatu, SP - Brasil. \\ ${ }_{3}^{2} U N E S P / F C A$ - Programa de Pós-Graduação em Energia na Agricultura. \\ ${ }^{3}$ Bunge Fertilizantes S/A - Quadra 1112 Sul, Alameda 1-5, Lotes 1-10, Setor Ecoindustrial - 77024-171 - \\ Palmas, TO - Brasil. \\ ${ }_{5}^{4}$ UNESP/FCA - Depto. de Produção Vegetal - Programa de Pós-Graduação em Agricultura. \\ 'UNESP/FCA - Depto. de Recursos Naturais/Ciência do Solo. \\ *Corresponding author <crusciol@fca.unesp.br>
}

\begin{abstract}
Some crops have shown not to adapt to the no-tillage system (NTS) as a consequence of the compaction of the superficial soil layer. In a certain way, the mechanism used in seeders to open furrows for the deposition of fertilizers can have great importance in facilitating root penetration. This study was carried out to evaluate the influence of two fertilizer distribution mechanisms and $\mathrm{N}$ fertilization in upland rice (Oryza sativa) under NTS. The experiment was carried out in the growing seasons 2001/2002 and 2002/ 2003, in Botucatu, state of São Paulo, Brazil. A completely randomized block design was applied, with subdivided plots and four replications. Main plots consisted of two furrow opening mechanisms (furrow opener and double disk). Subplots consisted of four side dressing $\mathrm{N}$ levels $\left(0,40,80\right.$ and $\left.120 \mathrm{~kg} \mathrm{ha}^{-1}\right)$. The following parameters were evaluated: furrow and seed deposition depth, plant population, plant height, number of stems and panicles $\mathrm{m}^{-2}$, number of spikelets per panicle, spikelet fertility, weight of 1,000 grains, shoot dry matter, grain yield and $\mathrm{N}$ levels in the flag leaf. The success for upland rice establishment under the NTS in dry winter regions of Brazil is directly associated to the furrow opening mechanism of the seed-drill. The furrow opener mechanism resulted in deeper seed deposition, consequently decreasing seedling population, number of panicles per area and grain yield. Side dressing $\mathrm{N}$ fertilization in upland rice under NTS increases grain yield whenever the double disk mechanism is used to sow.
\end{abstract}

Key words: Oryza sativa L., furrow opener, double disk, $\mathrm{N}$ doses

\section{Mecanismos de distribuição de fertilizante e adubação nitrogenada em cobertura no arroz de terras altas em sistema plantio direto}

\begin{abstract}
RESUMO: Algumas culturas têm pouca adaptação ao sistema plantio direto (SPD), em vista da alta compactação da camada superficial do solo. Nesse caso, o mecanismo utilizado na semeadora para a abertura dos sulcos para deposição do fertilizante pode ter grande importância no sentido de facilitar a penetração das raízes. Avaliouse a influência do mecanismo de distribuição de fertilizante e da adubação nitrogenada na cultura do arroz de terras altas (Oryza sativa) no sistema plantio direto. O experimento foi conduzido nos anos agrícolas 2001/ 2002 e 2002/2003, em Botucatu-SP, Brasil. O delineamento experimental foi em blocos casualizados, com parcelas subdivididas e quatro repetições. As parcelas foram constituídas por dois mecanismos de distribuição de fertilizantes (haste sulcadora e disco duplo). Nas subparcelas, quatro níveis de $\mathrm{N}$ foram aplicados em cobertura $\left(0,40,80\right.$ e $\left.120 \mathrm{~kg} \mathrm{ha}^{-1}\right)$. Avaliou-se a profundidade de abertura do sulco e de deposição das sementes, a população de plantas, a altura de plantas, o número de colmos e de panículas $\mathrm{m}^{-2}$, o número total de espiguetas por panícula, a fertilidade das espiguetas, a massa de 1.000 grãos, a matéria seca da parte aérea, a produtividade e o teor de $\mathrm{N}$ na folha bandeira. O sucesso no estabelecimento da cultura do arroz de terras altas no SPD nas regiões de inverno seco do Brasil está diretamente ligado ao mecanismo de distribuição das semeadoras-adubadoras. A haste sulcadora promoveu maior profundidade de deposição de sementes, conseqüentemente reduzindo o estande, o número de panículas por área e a produtividade. A aplicação de $\mathrm{N}$ em cobertura no arroz de terras altas em SPD proporciona maiores produtividades quando a semeadura é realizada com mecanismo de disco duplo.

Palavras-chave: Oryza sativa L., haste sulcadora, disco duplo, doses de N
\end{abstract}

\section{Introduction}

One of the major problems that producers face is to properly adapt the seed-drill for the no-tillage system (NTS). Therefore, depth for seed deposition may vary, and there might be a decrease in seed/soil contact and fertilizers may be distributed superficially. This process may decrease seed germination and restrict root development to upper soil layers, subsequently decreasing root volume and growth to deeper layers. As a conse-

Sci. Agric. (Piracicaba, Braz.), v.67, n.5, p.562-569, September/October 2010 
quence grain yield decreases especially under drought conditions (Silva et al., 2000). Furthermore, the seed-drill would have to be efficient in cutting the plant residues left on the surface and distributing fertilizers to appropriate depths.

Soil structure may be improved by the use of a furrow opener mechanism for fertilizer deposition (Gassen and Gassen, 1996), since this mechanism can increase root volume, root growth to deeper soil layers and plant tolerance to drought. However, higher soil mobilization may take place in the furrow, resulting in deeper seed deposition and increased particle desegregation (Araújo et al., 2001). Conversely, the deposition mechanism with double disk opens the furrow by compression and it is moved by disk rotation, thus it is prone to be affected by the amount of plant residues on soil surface, especially under the no-tillage system Schlosser et al. (1999). Such type of mechanism is less efficient under compacted soil conditions.

Nitrogen $(\mathrm{N})$ fertilization of the no-tillage system (NTS) may also limit upland rice yield (Mauad et al., 2003). Nevertheless, there is little information about $\mathrm{N}$ rates to be applied in cropping areas under this system in Brazil. For the conventional system, recommended rates vary from 50 to $70 \mathrm{~kg} \mathrm{ha}^{-1}$ of $\mathrm{N}$ (van Raij et al., 1996). High $\mathrm{N}$ rates increase yield components and final yield because the crop residues maintained on the soil surface affect nutrient dynamics over time (Bordin et al., 2003; Farinelli et al., 2004). The furrow opener mechanism increases $\mathrm{N}$ availability to plants due to higher soil mobilization. In this case, $\mathrm{N}$ levels become available due to higher organic matter mineralization and nitrification caused by better aeration. The double disk mechanism provides less soil mobilization and thus seeds remain in contact with the soil. Hence, seedlings have better conditions to develop properly and demand more $\mathrm{N}$ for growth.

The objective of this study was to evaluate the influence of fertilizer distribution mechanisms and $\mathrm{N}$ fertilization in upland rice under the no-tillage system.

\section{Material and Methods}

The experiment was carried out on a Rhodic Ferralsol (FAO, 2006) in 2001/2002 and 2002/2003, in

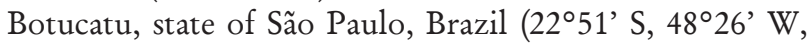
$770 \mathrm{~m}$ asl). The area had been cropped under the NTS since 1997. The average slope is $4.5 \%$ with west side exposition. Climate is Cwa according to Köeppen, with dry winter and hot wet summer (Lombardi Neto and Drugowich, 1994).

A completely randomized block design was used with subdivided plots and four replications. Main plots consisted of two furrow opening mechanisms (furrow opener and double disk). Subplots (5.4-m wide and 12-m long) consisted of four side dressing nitrogen levels ( 0 , 40,80 and $120 \mathrm{~kg} \mathrm{ha}^{-1}$ of N).

Soil samples were taken from the $0-20 \mathrm{~cm}$ surface layer for soil chemical analysis (van Raij et al., 2001), resulting: $\mathrm{pH}\left(\mathrm{CaCl}_{2}\right.$ 0.01M): 4.7; organic matter: $24 \mathrm{~g} \mathrm{dm}^{-3}$; $\mathrm{P}_{\text {resin }}: 21 \mathrm{mg} \mathrm{dm}^{-3} ; \mathrm{H}+\mathrm{Al}: 69 \mathrm{mmol} \mathrm{dm}_{\mathrm{c}}^{-3} ; \mathrm{K}: 1.1 \mathrm{mmol}_{\mathrm{c}}$ $\mathrm{dm}^{-3}$; Ca: $36 \mathrm{mmol} \mathrm{dm}^{-3}$; Mg: $17 \mathrm{mmol}_{\mathrm{c}} \mathrm{dm}^{-3}$ and $44 \%$ of base saturation. The granulometric analysis indicated $190 \mathrm{~g} \mathrm{~kg}^{-1}, 150 \mathrm{~g} \mathrm{~kg}^{-1}$ and $660 \mathrm{~g} \mathrm{~kg}^{-1}$ of sand, silt and clay, respectively. Soil bulk density was $1.32 \mathrm{mg} \mathrm{m}^{-3}$. Lime ECC (effective calcium carbonate equivalence: $92 \%$ ) was applied over the crop residue layer to raise base saturation up to $50 \%$ (van Raij et al., 1996).

In the first year (2001/2002), rice was sown over triticale (X Triticosecale Wittmack) residues $\left(5,700 \mathrm{~kg} \mathrm{ha}^{-1}\right.$ of triticale residues; $22.9 \%$ of soil water content by weight). In the second year (2002/2003), rice was sown over black oat (Avena strigosa Schreb.) residues $\left(7,000 \mathrm{~kg} \mathrm{ha}^{-1}\right.$ of black oat residues; $20.2 \%$ of soil water content). Before sowing, dessication was carried out with the systemic, non-selective herbicide glyphosate (480 $\mathrm{g}$ of active ingredient $\mathrm{L}^{-1}$ ) at a rate of $3 \mathrm{~L} \mathrm{ha}^{-1}$, in both years.

The upland rice cultivar 'IAC 202' was mechanically sown on December $11^{\text {th }} 2001$ and November $22^{\text {nd }} 2002$ in a $0.45-\mathrm{m}$ row spacing. The seed-drill was adjusted to sow 100 and 180 seeds $\mathrm{m}^{-1}$ down to $4 \mathrm{~cm}$ in 2001 and 2002, respectively. For furrow fertilization, $240 \mathrm{~kg}$ of the $04-$ 14-08 NPK formula were applied at a rate of $10.8 \mathrm{~g} \mathrm{~m}^{-1}$ of the fertilizer down to $10 \mathrm{~cm}$. Seedling emergence took place on December $17^{\text {th }} 2001$ and December $1^{\text {st }} 2002$.

The herbicides glyphosate and oxadiazon were combined for pre-emergence weed control $(2,377.5 \mathrm{~g}$ and $1,000 \mathrm{~g}$ of active ingredient $\mathrm{ha}^{-1}$, respectively). For postemergence weed control, propanil and 2.4-D (340 $\mathrm{g} \mathrm{L}^{-1}$ and $28 \mathrm{~g}$ of active ingredient $\mathrm{L}^{-1}$ ) were applied at a rate of $8 \mathrm{~L} \mathrm{ha}^{-1} 20$ days after emergence (DAE). Herbicides were applied with a spray boom calibrated for $250 \mathrm{~L}$ of solution $\mathrm{ha}^{-1}$. Side dressing nitrogen was applied at tillering, using urea. Harvest took place in April 2002.

Right after mechanical sowing, furrow and seed deposition depths were evaluated. After seedling emergence, the following parameters were evaluated: population of emerged seedlings, plant height, number of stems $\mathrm{m}^{-2}$, number of panicles $\mathrm{m}^{-2}$, total number of spikelets per panicle, spikelet fertility, mass of 1000 grains, shoot dry matter, grain yield and flag leaf nitrogen level.

Variance analysis was applied for statistical analysis. Whenever no significant interaction was found, means for the furrow opening mechanisms were compared by the test $(p \leq 0.05)$ and $\mathrm{N}$ rates by regression analysis. Whenever significant interaction was observed, the $t$ test $(p \leq 0.05)$ was applied and interaction slicing was used to compare distribution mechanisms for each $\mathrm{N}$ rate. Regression analysis was also used to evaluate $\mathrm{N}$ fertilization for each distribution mechanism, choosing the significant equations of higher coefficients of determination.

\section{Results and Discussion}

Furrow opening mechanisms affected furrow opening depth, seed deposition depth and seedling population in both years (Table 1), indicating that furrows were 
deeper whenever opened with the furrow opener compared to the double disk. The furrow opener penetrates soil deeper and increases mobilization, especially in more clayey and moistened soils (Schlosser et al. 1999), also being less affected by the crop residues that remain in no tillage operations. Conversely, double disks penetrate soil through $\mathrm{V}$-shaped compression and move by rolling on the surface. These operation characteristics are influenced by the amount of crop residues left on soil surface, resulting in superficial furrow opening. Araújo et al. (1999) also reported that the furrow opener opens seed furrows down to $15 \mathrm{~cm}$, which is deeper compared to the double disk, but it demands more power from the tractor.

In both years, seeds were placed deeper with the furrow opener, probably because a deeper furrow was opened, affecting the sowing depth (Table 1). In clayey soils, the furrow may not be closed after opening because of low soil disaggregation, causing seeds to be placed deeper. In sandy soils, this effect is reduced because of high disaggregation. Fertilizer deposition depth may affect the sowing depth because of the greater soil displacement, depositing it at furrow sides where depth-controlling wheels transit (Silva et al., 2000).

The recommended depth for upland rice sowing ranges from 3 to $5 \mathrm{~cm}$ (Breseghello, 1998). Superficial sowing causes faster seedling emergence and increases competition with weed species, also preventing seeds from consuming excessive amount of reserve for emergence.
Higher seedling population was observed using the double disk mechanism in both years (Table 1), probably due to superficial sowing and faster seedling emergence. On the other hand, the furrow opener allowed seeds to be sown deeper down the soil profile, causing slow germination and initial seedling growth. Also, this mechanism may have shown furrow closure failures, producing air spaces that avoid seeds from being fully in contact with soil, causing seedling population to be lower. Another possibility is that aggregate sizes in the furrow may have increased the distance for seedlings to emerge above soil surface (Araújo et al., 2001). Both heat and moisture exchange provided by seed/soil contact assure efficient germination and high yield. During seed germination, moisture and oxygen are fundamental and must be appropriately provided (Fornasieri Filho and Fornasieri, 1993).

Plant height was affected by the interaction between furrow opening mechanisms and nitrogen rates in the first year (Table 2, Figure 1A). The double disk mechanism caused plant height to increase with higher $\mathrm{N}$ rates up to the estimated rate of $74 \mathrm{~kg} \mathrm{ha}^{-1}$. However, higher $\mathrm{N}$ rates decreased plant height because they may have stimulated plants to an excessive growth, competing for water, light and nutrients. Similar results were found by Arf et al. (2003) and Mauad et al. (2003). Plant height increased linearly in response to $\mathrm{N}$ rates when the furrow opener was used (Figure 1A) probably due to lower seedling population caused by this type of distribution

Table 1 - Furrow opening depth, seed deposition depth and seedling population of rice affected by furrow opening mechanisms in 2001/2002 and 2002/2003. Botucatu-SP.

\begin{tabular}{|c|c|c|c|c|c|c|}
\hline \multirow{2}{*}{ Treatment } & \multicolumn{2}{|c|}{ Furrow opening depth } & \multicolumn{2}{|c|}{ Seed deposition depth } & \multicolumn{2}{|c|}{ Seedling population } \\
\hline & $2001 / 02$ & $2002 / 03$ & $2001 / 02$ & $2002 / 03$ & $2001 / 02$ & $2002 / 03$ \\
\hline & \multicolumn{4}{|c|}{ 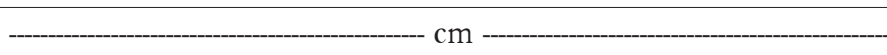 } & \multicolumn{2}{|c|}{....- seedlings $\mathrm{m}^{-1}$} \\
\hline \multicolumn{7}{|c|}{ Opening mechanism } \\
\hline Double Disk & $6.8 \mathrm{~b}$ & $7.3 \mathrm{~b}$ & $4.7 \mathrm{~b}$ & $4.9 \mathrm{~b}$ & $92 \mathrm{a}$ & $155 \mathrm{a}$ \\
\hline Furrow Opener & $14.2 \mathrm{a}$ & $14.4 \mathrm{a}$ & $6.6 \mathrm{a}$ & $6.8 \mathrm{a}$ & $71 \mathrm{~b}$ & $130 \mathrm{~b}$ \\
\hline $\mathrm{F}_{\text {treatment }}$ & 705.62 & 1963.25 & 504.81 & 1704.99 & 30.86 & 99.73 \\
\hline $\mathrm{CV}(\%)$ & 7.39 & 4.16 & 4.20 & 2.19 & 13.5 & 5.03 \\
\hline LSD & 0.562 & 0.33 & 0.17 & 0.09 & 7.93 & 5.16 \\
\hline
\end{tabular}

Means followed by the same small letter in the column do not differ ( $\mathrm{F}$ test, $p \leq 0.05)$.

Table 2 - Plant height, number of stems and panicles per $\mathrm{m}^{-2}$ of rice affected by furrow opening mechanisms in 2001/2002 and 2002/2003. Botucatu-SP.

\begin{tabular}{|c|c|c|c|c|c|c|}
\hline \multirow{2}{*}{ Treatment } & \multicolumn{2}{|c|}{ Plant height } & \multicolumn{2}{|c|}{ Stems } & \multicolumn{2}{|c|}{ Panicles } \\
\hline & $2001 / 02$ & $2002 / 03$ & $2001 / 02$ & $2002 / 03$ & $2001 / 02$ & $2002 / 03$ \\
\hline & \multicolumn{2}{|c|}{ 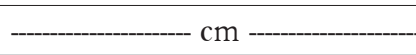 } & 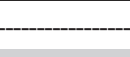 & nu & $\mathrm{I}^{-2}-$ & - \\
\hline \multicolumn{7}{|c|}{ Opening mechanism } \\
\hline Double Disk & $77.7 \mathrm{a}$ & $60.1 \mathrm{a}$ & $153 \mathrm{a}$ & $232 a$ & $113 \mathrm{a}$ & $180 \mathrm{a}$ \\
\hline Furrow Opener & $76.7 \mathrm{a}$ & $61.8 \mathrm{a}$ & $97 \mathrm{~b}$ & $184 \mathrm{~b}$ & $74 \mathrm{~b}$ & $125 \mathrm{~b}$ \\
\hline CV plots (\%) & 3.32 & 6.12 & 18.26 & 8.92 & 21.65 & 4.51 \\
\hline
\end{tabular}

Means followed by the same small letter in the column do not differ (F test, $p \leq 0.05$ ). 

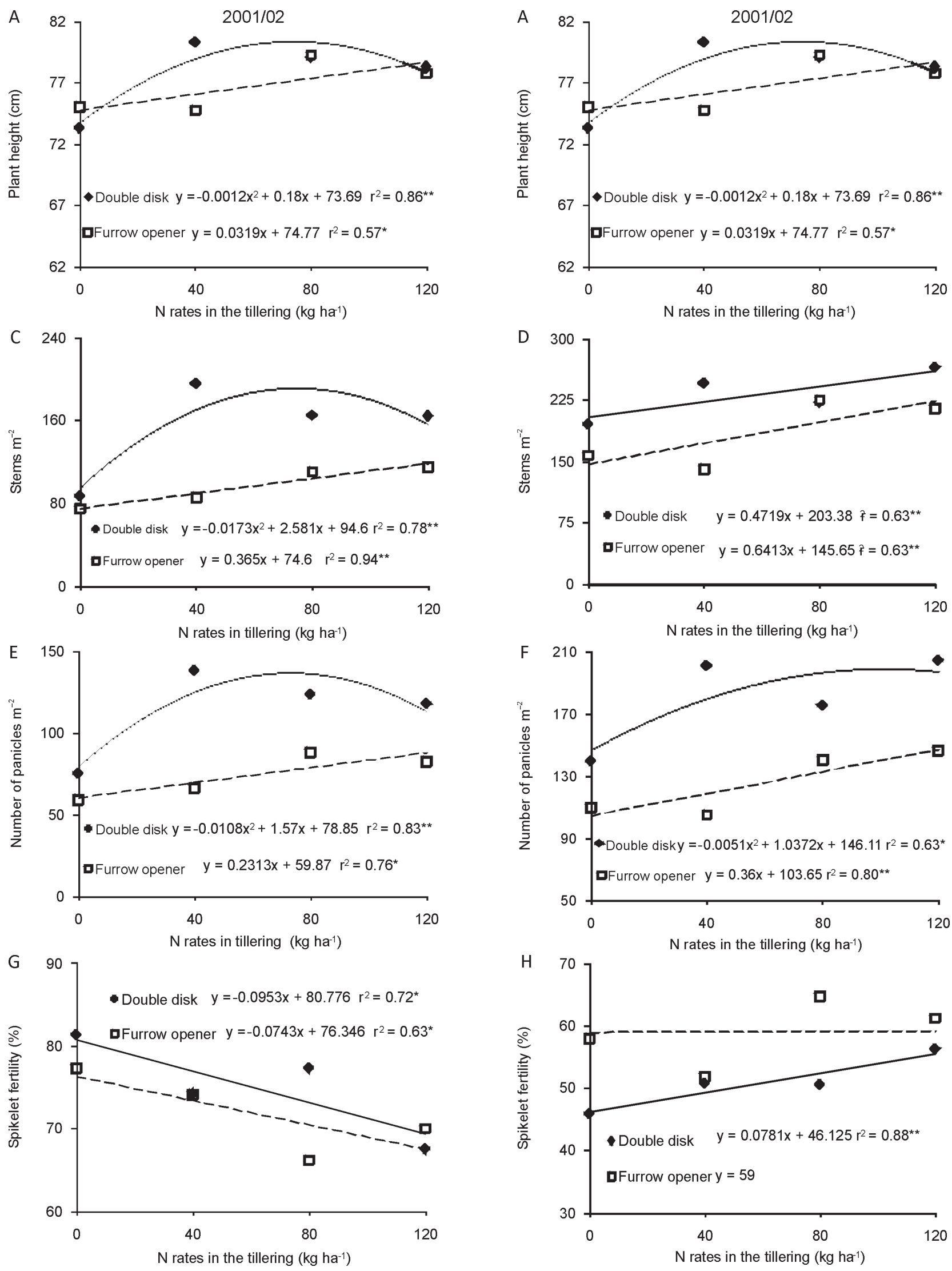

Figure 1 - Plant height (A and B), number of stems per $\mathrm{m}^{2}(\mathrm{C}$ and $\mathrm{D})$, panicles per $\mathrm{m}^{2}$ (E and F), spikelet fertility $(\mathrm{G}$ and $\mathrm{H})$ of rice affected by $\mathrm{N}$ rates and furrow opening mechanisms in 2001/2002 and 2002/2003, respectively. Botucatu-SP. *, ** significant at 5 and $1 \%$, respectively. 
mechanism (Table 1), contributing to lower competition even with higher rates.

In the second year, plant height was also influenced by the interactive effect of opening mechanisms and $\mathrm{N}$ rates (Table 2, Figure 1B). Values obtained with the double disk mechanism linearly increased with $\mathrm{N}$ rates. Diniz et al. (1976) and Santos et al. (1986) have also observed the effects of increasing $\mathrm{N}$ rates on plant height Additionally, Freitas et al. (2001) observed that plant height increases with wider row spacing and higher $\mathrm{N}$ rates.

In the first year, the number of stems $\mathrm{m}^{-2}$ was affected by the interaction among treatments (Table 2). Higher number of stems $\mathrm{m}^{-2}$ was observed for the double disk mechanism (153 stems $\left.\mathrm{m}^{-2}\right)$. The furrow opener caused the number of stems $\mathrm{m}^{-2}$ to be lower $\left(97\right.$ stems $\mathrm{m}^{-2}$ ) probably because of the deeper sowing depth (Table 1), lower seedling population (Table 1). The development of lower auxiliary buds and tillering may also have been inhibited (Fornasieri Filho and Fornasieri, 1993).

The number of stems was increased by $\mathrm{N}$ fertilization up to the rate of $81 \mathrm{~kg} \mathrm{ha}^{-1}$ when the double disk mechanism was used in the first year (Figure 1C). Once more, $\mathrm{N}$ may have stimulated tillering until plants started to compete for water, light and nutrients, decreasing the number of stems even with higher fertilizer rates (Stone et al., 1979; Fageria, 1984). However, the furrow opener mechanism caused the number of stems to increase linearly with higher $\mathrm{N}$ rates. The double disk mechanism showed distinct effects, for seeds are placed deeper in soil which results in lower initial number of stems. Fornasieri Filho and Fornasieri (1993) and Mauad et al. (2003) have also reported that $\mathrm{N}$ fertilization increases the number of stems.

In the second year, the number of stems $\mathrm{m}^{-2}$ was affected linearly by $\mathrm{N}$ rates combined with the deposition mechanism (Table 2, Figure 1D). Similarly to the first year, higher number of stems $\mathrm{m}^{-2}$ was obtained using the double disk (232 stems $\mathrm{m}^{-2}$ ) compared to the furrow opener (184 stems $\left.\mathrm{m}^{-2}\right)$, even with the higher seed density of the second year. The number of panicles $\mathrm{m}^{-2}$ was higher using the double disk (113 panicles $\mathrm{m}^{-2}$ ) for fertilizer distribution compared to the furrow opener (74 panicles $\mathrm{m}^{-2}$ ), similarly as in relation to the number of stems $\mathrm{m}^{-2}$ (Table 2). These results reflected higher sow- ing depth (Table 1), which decreased seedling emergence and, consequently, the number of stems and panicles $\mathrm{m}^{-2}$.

In 2001/2002, the number of panicles $\mathrm{m}^{-2}$ increased with the application of $\mathrm{N}$ up to the rate $73 \mathrm{~kg} \mathrm{ha}^{-1}$ along with the use of the double disk (Figure 1E), in a similar way as the number of stems $\mathrm{m}^{-2}$. Nitrogen fertilization stimulated tillering and increased the number of panicles until plants started to compete for water, light and nutrients. At this point, the number of tillers and panicles started to decrease with higher $\mathrm{N}$ rates (Stone et al., 1979; Fageria, 1984). Guimarães and Stone (2003) found similar results for the upland rice cv. 'Canastra'.

Higher $\mathrm{N}$ rates linearly increased the number of panicles $\mathrm{m}^{-2}$ when the furrow opener mechanism was used (Figure 1E) because of the lower initial number of stems and seedling population. Therefore, no tiller competition was observed with increasing $\mathrm{N}$ rates and more vegetative buds turned into reproductive ones. Rice requires nitrogen during the vegetative stage to increase the number of tillers as well as the number of panicles. In the second year, the number of panicles $\mathrm{m}^{-2}$ was affected by the furrow opening mechanism combined with nitrogen rates (Table 2, Figure 1F). Higher number of panicles $\mathrm{m}^{-2}$ was observed for the double disk (180 panicles $\left.\mathrm{m}^{-2}\right)$ in comparison to the furrow opener (125 panicles $\mathrm{m}^{-2}$ ). The highest number of panicles $\mathrm{m}^{-2}$ was obtained with $102 \mathrm{~kg}$ of $\mathrm{N} \mathrm{ha}^{-1}$, with a subsequent decrease with higher rates. Conversely, the furrow opener mechanism increased linearly the number of panicles $\mathrm{m}^{-2}$, as in the first year.

The total number of spikelets per panicle was affected by the interaction between treatments in the first year (Table 3, Figure 2C). Nitrogen rates increased the number of spikelets per panicle up to the rate of $74 \mathrm{~kg}$ $\mathrm{ha}^{-1}$ for the furrow opener, although a lower number of stems and panicles $\mathrm{m}^{-2}$ was observed for this mechanism (Table 3). This result can be explained by the capability of rice plants to compensate the lower number of panicles by producing more spikelets per panicle (Sousa et al., 1995). Stone et al. (1999) studied the effect of nitrogen rates in upland rice and found similar responses of the total number of spikelets per panicle. In 2002/ 2003, higher number of spikelets per panicle was observed for the furrow opener (222 spikelets $\mathrm{pan}^{-1}$ ) com-

Table 3 - Total number of spikelets per panicle, spikelet fertility and weight of 1000 rice grains affected by furrow opening mechanisms in 2001/2002 and 2002/2003. Botucatu-SP.

\begin{tabular}{|c|c|c|c|c|c|c|}
\hline \multirow{2}{*}{ Treatment } & \multicolumn{2}{|c|}{ Spikelets } & \multicolumn{2}{|c|}{ Spikelet fertility } & \multicolumn{2}{|c|}{ Weight of 1000 grains } \\
\hline & $2001 / 02$ & $2002 / 03$ & $2001 / 02$ & $2002 / 03$ & $2001 / 02$ & $2002 / 03$ \\
\hline & \multicolumn{2}{|c|}{$\mathrm{n}^{\mathrm{e}}$ panicles $^{-1}$} & \multicolumn{2}{|c|}{ \% $\%$} & \multicolumn{2}{|c|}{ 每- g g } \\
\hline \multicolumn{7}{|c|}{ Opening mechanism } \\
\hline Double Disk & $188 \mathrm{a}$ & $177 \mathrm{~b}$ & $75 \mathrm{a}$ & $51 \mathrm{~b}$ & 20.4 & $16.6 \mathrm{~b}$ \\
\hline Furrow Opener & $193 \mathrm{a}$ & $222 \mathrm{a}$ & $72 \mathrm{a}$ & $59 \mathrm{a}$ & 21.1 & $17.3 \mathrm{a}$ \\
\hline CV plots (\%) & 5.78 & 7.65 & 8.12 & 8.02 & 8.38 & 2.95 \\
\hline
\end{tabular}

Means followed by the same small letter in the column do not differ (F test, $p \leq 0.05)$. 
pared to double disk (177 spikelets pan $^{-1}$ ) (Table 3), although the furrow opener had shown a lower number of stems and panicles $\mathrm{m}^{-2}$ (Table 2), as observed in the first year.

Spikelet fertility decreased with increasing nitrogen rates for both furrow opening mechanisms in the first year (Figure 1G). Whenever the furrow opener was used as fertilizer distribution mechanism, $\mathrm{N}$ rates also increased plant height and the number of stems and panicles $\mathrm{m}^{-2}$, which might have decreased spikelet fertility. In this case, $\mathrm{N}$ application may have increased tillering, inducing competition and reducing transfer of photoassimilates to rice grains in formation. Similar results were found by Mauad et al. (2003).

In the second year, spikelet fertility was affected by the furrow opening mechanism combined with $\mathrm{N}$ rates (Table 3). Spikelet fertility was lower compared to the previous year, especially due to drought at the booting stage and in the beginning of spikelet filling. Therefore, lower water availability probably increased the number of sterile spikelets because photoassimilate translocation to spikelets was reduced. Crusciol et al. (2003) concluded that drought causes spikelet fertility to be reduced in the dryland system as a result of lower photoassimilate translocation to grains. Spikelet fertility increased linearly with nitrogen rates in the second year when furrows were opened with double disk (Figure 1H). Nitrogen rates did not affect the results for the furrow opener, but this mechanism provided higher values than the double disk, even with the application of the highest $\mathrm{N}$ rate.

The weight of 1,000 grains was not affected by the treatments in the first year (Table 3). Stone et al. (1979), Stone and Silva (1998) and Stone et al. (1999) also observed that $\mathrm{N}$ fertilization did not influence the grain weight. Mauad et al. (2003) observed that the weight of 1000 grains decreased with higher $\mathrm{N}$ rates, because car- bohydrates were not sufficient to fill the greater number of spikelets. In the second year, only furrow opening mechanisms affected grain weight (Table 3). The furrow opener resulted in higher weight of 1000 grains, probably compensating the lower number of stems and panicles $\mathrm{m}^{-2}$ (Table 2). To produce well formed grains, higher translocation of photoassimilates may have occurred. The weight of 1,000 grains for both mechanisms was lower compared to the previous year, probably due to drought that had occurred right before flowering.

Shoot dry matter was influenced by all treatments in both years (Table 4). In the first year, $\mathrm{N}$ fertilization linearly increased shoot dry matter for both furrow opening mechanisms (Figure 2A). Comparing each $\mathrm{N}$ rate individually, shoot dry matter was higher whenever furrows were opened with double disk, probably due to the higher number of stems and panicles $\mathrm{m}^{-2}$. Similarly to the previous year, shoot dry matter increased linearly with $\mathrm{N}$ rates and the double disk mechanism in 2002/ 2003 (Figure 2B).

Grain yield was affected by the distribution mechanism (Table 4) in the first year. The double disk increased grain yield by $48 \%$ compared to the furrow opener due to the higher number of stems and panicles $\mathrm{m}^{-2}$ observed for this mechanism. In 2001/2002, both mechanisms increased grain yield up to certain rates with subsequent decrease (Figure 2E). With the double disk, a maximum grain yield of $2170 \mathrm{~kg} \mathrm{ha}^{-1}$ was obtained with the estimated rate of $67 \mathrm{~kg} \mathrm{~N} \mathrm{ha}^{-1}$, which would be $16 \%$ higher than no side dressing $\mathrm{N}$ fertilization (estimation). For the furrow opener mechanism, a maximum grain yield $\left(1461 \mathrm{~kg} \mathrm{ha}^{-1}\right)$ was obtained with $72 \mathrm{~kg} \mathrm{~N} \mathrm{ha}^{-1}$, which is $15 \%$ higher than no $\mathrm{N}$ application. Meira et al. (2005) observed that the rice yield increased with $\mathrm{N}$ fertilization as well. The authors obtained maximum grain yield with $90 \mathrm{~kg} \mathrm{ha}^{-1}$ of $\mathrm{N}$.

Table 4 - Shoot dry matter, grain yield and $\mathrm{N}$ level in the leaf flag of rice affected by $\mathrm{N}$ rates and furrow opening mechanisms in 2001/2002 and 2002/2003. Botucatu-SP.

\begin{tabular}{|c|c|c|c|c|c|c|}
\hline \multirow{2}{*}{ Treatment } & \multicolumn{2}{|c|}{ Shoot dry matter } & \multicolumn{2}{|c|}{ Grain yield } & \multicolumn{2}{|c|}{$\mathrm{N}$ level in the leaf flag } \\
\hline & $2001 / 02$ & $2002 / 03$ & $2001 / 02$ & $2002 / 03$ & $2001 / 02$ & $2002 / 03$ \\
\hline & \multicolumn{4}{|c|}{ long ha ${ }^{-1}$} & \multicolumn{2}{|c|}{$\mathrm{kg} \mathrm{ha}^{-1}$} \\
\hline \multicolumn{7}{|c|}{ Opening mechanism } \\
\hline Double Disk & 4726 a & $5445 \mathrm{a}$ & 2035 a & 398 & $37.28 \mathrm{~b}$ & 31.94 \\
\hline Furrow Opener & $3698 \mathrm{~b}$ & $4493 \mathrm{~b}$ & $1380 \mathrm{~b}$ & 406 & 41.12 a & 32.12 \\
\hline \multicolumn{7}{|l|}{$\mathrm{N}$ rates $\left(\mathrm{kg} \mathrm{ha}^{-1}\right)$} \\
\hline 0 & 3111 & 4579 & 1566 & 410 & 39.12 & 29.75 \\
\hline 40 & 4074 & 5070 & 1782 & 451 & 38.68 & 32.88 \\
\hline 80 & 4296 & 5113 & 1798 & 372 & 38.37 & 32.00 \\
\hline 120 & 4778 & 5114 & 1684 & 375 & 40.62 & 33.50 \\
\hline CV plots (\%) & 21.41 & 16.28 & 3.77 & 12.05 & 7.06 & 6.52 \\
\hline CV split plots (\%) & 9.83 & 9.92 & 2.58 & 13.30 & 6.08 & 4.70 \\
\hline
\end{tabular}

Means followed by the same small letter in the column do not differ (F test, $p \leq 0.05$ ). 
Crusciol et al.
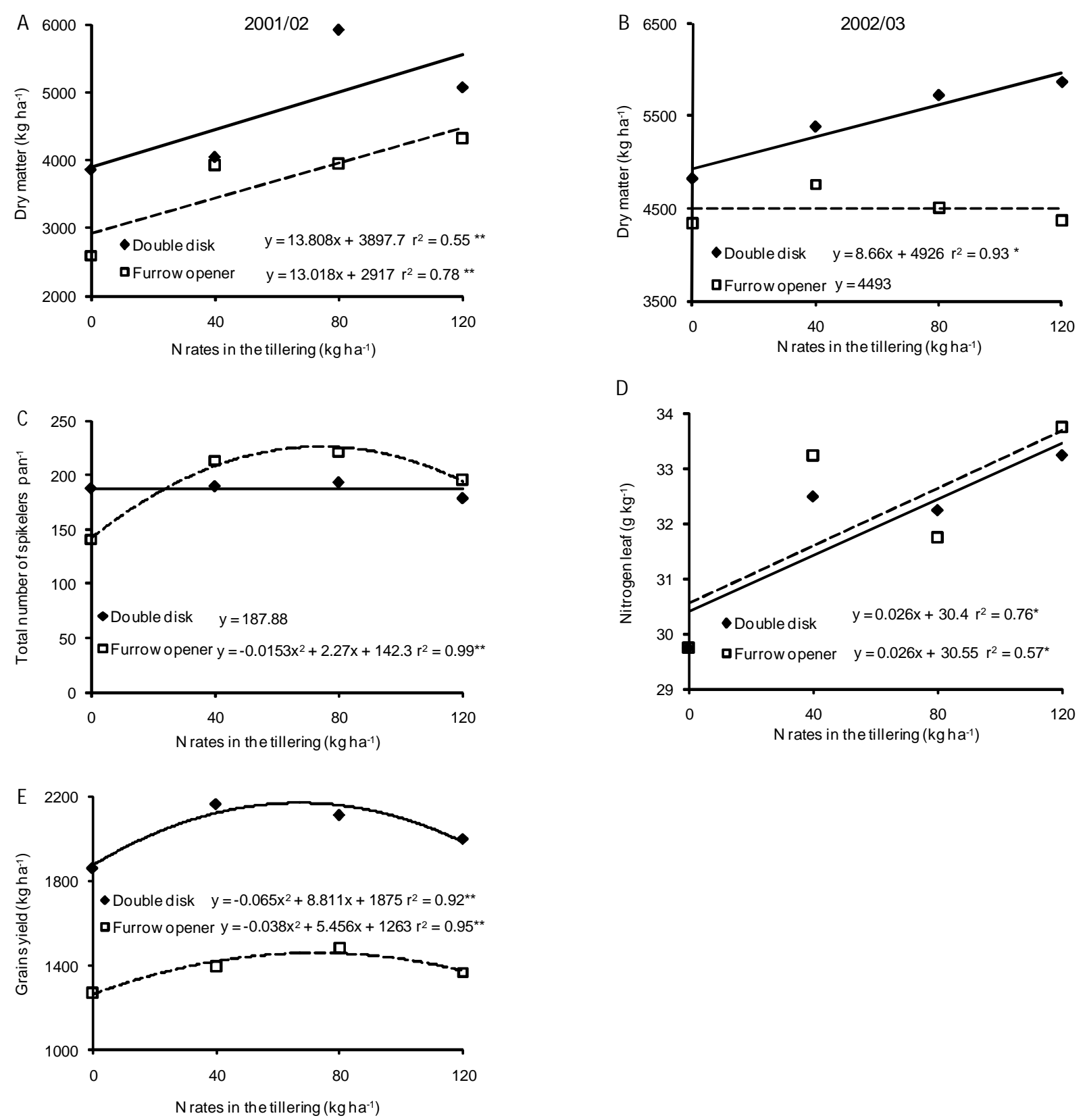

Figure 2 - Shoot dry matter (A), total number of spikelets (C) and rice yield (E)obtained in 2001/2002, and shoot dry matter (B) and $\mathrm{N}$ level in the leaf flag (D) in 2002/2003 affected by $\mathrm{N}$ rates and furrow opening mechanisms. Botucatu-SP. *, ** significant at 5 and $1 \%$, respectively.

Higher grain yield was obtained with the double disk due to higher number of stems and panicles $\mathrm{m}^{-2}$ (Table 2), lower sowing depth (Table 1) and, consequently, higher initial seedling population (Table 1). Nevertheless, Arf et al. (2008) evaluated the same distribution mechanisms for bean sowing and obtained higher plant population and grain yield with the furrow opener. Similarly to the results of this experiment, Arf et al. (2008) reported that the furrow opener placed seeds deeper in soil. However, bean seeds have greater amount of reserve material for seedling development and thus plant population reduction was not observed. None of the treatments affected grain yield in the second year (Table 4). Grain yield was likely influenced by drought experienced by plants at reproductive and maturation stages, which may have decreased spikelet fertility and grained spikelets per panicle.

The $\mathrm{N}$ level in the flag leaf was lower when furrows were opened with the double disk in the first year (Table 4) due to the dilution effect resulting from higher dry matter production, number of stems and panicles $\mathrm{m}^{-2}$. In the second year, $\mathrm{N}$ content was affected only by $\mathrm{N}$ fertilization. Nitrogen rates increased linearly the $\mathrm{N}$ content in the flag leaf independently of the furrow opening mechanism (Figure 2D). According to van Raij et al. (1996) $\mathrm{N}$ levels were within the range $\left(27-35 \mathrm{~g} \mathrm{~kg}^{-1}\right)$ considered appropriate for rice in both years. 


\section{Conclusions}

The furrow opener mechanism resulted in deeper seed deposition, consequently decreasing seedling population, number of panicles per area and grain yield under soil moisture and coverage conditions of this experiment. Side dressing $\mathrm{N}$ fertilization in upland rice under the NTS increases grain yield when the double disk mechanism is used for sowing.

\section{References}

Araújo, A.G.; Casão Junior, R.; Siqueira, R. 2001. Mechanization of tillage: problems and solutions. IAPAR, Três Marcos, PR, Brazil. (Informe da Pesquisa, Londrina, 137). 18p. (in Portuguese).

Araújo, A.G.; Casão Junior, R.; Ralisch, R.; Siqueira, R. 1999. Soil mobilization and seedling emergence in no-till of soybean (Glycine max L.) and maize (Zea mays L.) in clayey soils. Engenharia Agrícola 19: 226-237. (in Portuguese, with abstract in English).

Arf, O.; Rodrigues, R.A.F.; Crusciol, C.A.C.; Sá, M.E.; Buzetti, S. 2003. Soil management and nitrogen fertilization for sprinklerirrigated upland rice cultivars. Scientia Agricola 60: 345-352. (in Portuguese, with abstract in English).

Arf, O.; Afonso, R.J.; Romanini Júnior, A.; Silva, M.G. 2008. Furrows opening mechanism for nitrogen fertilizer application in common bean crop under no-tillage. Bragantia 67: 499-506. (in Portuguese, with abstract in English).

Bordin, L.; Farinelli, R.; Penariol, F.G.; Fornasieri Filho, D. 2003. Double crop: commom bean with upland rice, submitted to rates of nitrogen fertilization after green cover under no-tillage system. Bragantia 62: 235-241. (in Portuguese, with abstract in English).

Breseghello, F. Sowing of rice. In: Breseghello, F.; Stone, L.F. 1998. Technology for upland rice. Embrapa Arroz e Feijão, Santo Antônio de Goiás, GO, Brazil. p. 55-58. (in Portuguese).

Crusciol, C.A.C.; Arf, O.; Soratto, R.P.; Machado, J.R. 2003. Influence of water levels and mineral fertilization on nutrition and yield of upland rice. Revista Brasileira de Ciência do Solo 27: 647-654. (in Portuguese, with abstract in English).

Diniz, J.A.; Brandão, S.S.; Giúdice, R.M.; Sediyama, C.S.; Loureiro, B.T. 1976. Upland rice performace under sprinkler irrigation at different nitrogen rates. Experientiae 22: 235-262. (in Portuguese).

Fageria, N.K. Fertilization and mineral nutrition of rice crop. 1984. Editora Campos, Rio de Janeiro, RJ, Brazil. (in Portuguese).

Food and Agriculture Organization [FAO]. 2006. World Reference Base for Soil Resources. FAO, Rome, Italy.

Farinelli, R.; Penariol, F.G.; Fornasieri Filho, D.; Bordin, L. 2004. Effects of nitrogen and potassium fertilization on agronomic characteristics of upland rice cultivated under no-tillage. Revista Brasileira de Ciência do Solo 28: 447-454. (in Portuguese, with abstract in English).

Freitas, J.G.; Azzini, L.E.; Cantarella, H.; Bastos, C.R.; Castro, L.H.S.M.; Gallo, P.B.; Felício, J.C. 2001. Response of irrigated rice cultivars to nitrogen. Scientia Agricola 58: 573-579. (in Portuguese, with abstract in English).
Fornasieri Filho, D.; Fornasieri, J.L., eds. 1993. Manual of Rice. FUNEP, Jaboticabal, SP, Brazil. (in Portuguese).

Gassen, D.N.; Gassen, F.R. 1996. No till: the path of future. Aldeia Sul, Passo Fundo, RS, Brazil. (in Portuguese).

Guimarães, C.M.; Stone, L.F. 2003. Nitrogen fertilization of upland rice under no-tillage system. Revista Brasileira de Engenharia Agrícola e Ambiental 7: 210-214. (in Portuguese, with abstract in English).

Lombardi Neto, F.; Drugowich, M.I., eds. 1994. Technical manual management and conservation of soil and water. 2ed. CATI, Campinas, SP, Brazil. (in Portuguese).

Mauad, M.; Crusciol, C.A.C.; Grassi Filho, H. 2003. Nitrogen and silicon fertilization of upland rice. Scientia Agricola 60: 761-765. (in Portuguese, with abstract in English).

Meira, F.A.; Buzetti, S.; Freitas, J.G.; Arf, O.; Sá, M.E. 2005. Two rice cultivars response to nitrogen fertilization and leaf fungicide treatment. Acta Scientiarum 27: 91-95. (in Portuguese, with abstract in English).

Santos, A.B.; Prabhu, A.S.; Aquino, A.S.; Aquino, A.R.L.; Carvalho, J.R.P. 1986. Date, methods of application e nitrogen levels on Piricularia oryzae and upland rice production. Pesquisa Agropecuária Brasileira 21: 697-707. (in Portuguese, with abstract in English).

Schlosser, J.F.; Bertol, O.J.; Bertol, I.; Lavoranti, O.J. 1999. Three seed drills for planting performance in the presence of different cover crops in winter. Engenharia Agricola 19: 64-70 (in Portuguese).

Silva, J.G.; Kluthcouski, J.; Silveira, P.M. 2000. Performance of a sowing-fertilizer machine for corn crop establishment and grain yield under no-tillage system. Scientia Agrícola 57: 7-12. (in Portuguese, with abstract in English).

Sousa, R.O.; Gomes, A.S.; Martins, J.F.S.; Penã, Y.A. 1995. Seeding rate and row spacing for irrigated rice under no-tillage. Revista Brasileira de Agrociência 1: 69-74. (in Portuguese, with abstract in English).

Stone, L.F.; Oliveira, A.B.; Steinmetz, S. 1979. Water deficit and response of upland rice cultivars to nitrogen. Pesquisa Agropecuária Brasileira 14: 295-301. (in Portuguese).

Stone, L.F.; Silva, J.G. 1998. Response of upland rice to ploughing depth, nitrogen fertilization, and soil water status. Pesquisa Agropecuária Brasileira 33: 891-897. (in Portuguese, with abstract in English).

Stone, L.F.; Silveira, P.M.; Moreira, J.A.A.; Yokoyama, L.P. 1999. Rice nitrogen fertilization under supplemental sprinkler irrigation. Pesquisa Agropecuária Brasileira 34: 927-932. (in Portuguese, with abstract in English).

Van Raij, B.; Andrade, J.C.; Cantarella, H.; Quaggio, J.A. 2001. Chemical Analysis for Evaluation. Instituto Agronômico, Campinas, SP, Brazil (in Portuguese).

Van Raij, B.; Cantarela, H.; Quaggio, J.A.; Furlani, A.M.C., eds. 1996. Lime and fertilizer recommendations for the State of Sao Paulo. Instituto Agronômico, Campinas, SP, Brazil. (Boletim Técnico, 100). (in Portuguese).

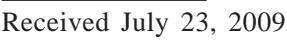

Accepted April 12, 2010 